\title{
ТЕОРЕТИЧНІ ОСНОВИ ТА КЛАСИФІКАЦІЯ РИЗИКІВ 3 ВРАХУВАННЯМ ОСОБЛИВОСТЕЙ ФУНКЦІОНУВАННЯ ПІДПРИЕМСТВ АГРАРНОГО СЕКТОРУ
}

\author{
THEORETICAL BASIS AND CLASSIFICATION \\ OF RISKS TAKING INTO ACCOUNT \\ THE FEATURES OF THE FUNCTIONING \\ OF AGRICULTURAL SECTOR ENTERPRISES
}

\author{
Кириченко Наталя Валеріївна \\ кандидат економічних наук, доцент, \\ Херсонський державний аграрно-економічний університет \\ ORCID: https://orcid.org/0000-0003-1721-258X \\ Алєщенко Людмила Олександрівна \\ асистент, \\ Херсонський державний аграрно-економічний університет \\ ORCID: https://orcid.org/0000-0002-7119-2922
}

Kyrychenko Natalia, Aleschenko Liudmyla

Kherson State Agrarian and Economic University

\begin{abstract}
У статті досліджено складові ризику в аграрному секторі економіки України, проведено аналіз параметрів бізнесу за видом економічної діяльності, розроблено авторський підхід до класифікації ризиків з урахуванням специфічних умов сільськогосподарських підприємств. Ґрунтовно проаналізовано понятійний апарат термінології обраної теми. Проаналізовано та узагальнено фрактори, які зумовлюють ризик у господарській діяльності аграрних підприємств. Авторами визначено особливості процесу управління ризиками в контексті менеджменту підприємств, його складові. Представлена оригінальна класифікація ризиків, з якими стикаються аграрні підприємства у процесі своєї господарської діяльності. Зроблено висновок, що запропонована класифікація може представляти практичний інтерес для господарюючих суб'єктів і використовуватися в якості моделі для створення власної кваліфрікаційної таблиці з урахуванням галузевих особливостей агровиробництва та стати одним 3 інструментів при прийнятті управлінських рішень, щодо побудови ефективної системи ризик менеджменту на підприємстві.

Ключові слова: ризики аграрних підприємств, класифікація ризиків, менеджмент, сільськогосподарське виробництво, ризик менеджмент.
\end{abstract}

В статье исследованы составляющие риска в аграрном секторе экономики Украины, проведен анализ параметров бизнеса по виду экономической деятельности, разработаны авторский подход к классификации рисков с учетом специфических условий сельскохозяйственных предприятий. Основательно проанализированы понятийный аппарат терминологии выбранной темы. Проанализированы и обобщены фракторы, которые обусловливают риск в хозяйственной деятельности аграрных предприятий. Авторами определены особенности процесса управления рисками в контексте менеджмента предприятий, его составляющие. Представлена оригинальная классисрикация рисков, с которыми сталкиваются аграрные предприятия в процессе своей хозяйственной деятельности. Сделан вывод, что предложенная классификация может представлять практический интерес для хозяйствующих субъектов и использоваться в качестве модели для создания собственной квалификационной таблицы с учетом отраслевых особенностей агропроизводства и стать одним из инструментов при принятии управленческих решений относительно построения эфрфективной системы риск менеджмента.

Ключевые слова: риски аграрных предприятий, классификация рисков, менеджмент, сельскохозяйственное производство, риск менеджмент.

Currently, the agricultural sector has the most risky area of activity. The risks of agricultural enterprises are the subject of scientific research, as they have a huge impact not only on the activities of economic entities, but also on the food security of the state as a whole. Conditions for the functioning and development of agricultural enter- 
prises are quite specific, which are not typical of other industries, it is dependent on natural conditions, seasonality of production, the complexity of innovation, regional, sectorial, functional, technological, organizational factors and features of living organisms in the production process. It should be noted that in the domestic and foreign economic literature there are mostly general principles of management of enterprises and production in conditions of uncertainty and risk. Despite the significant number, thoroughness and complexity of the research, some issues focused on the development of effective tools and mechanisms for predicting the risks of their classification in the operation and development of agricultural enterprises in the economic literature have not received unequivocal opinions. This is what determined the choice of tasks and purpose of this study. The article examines the components of risk in the agricultural sector of Ukraine's economy, analyzes the parameters of business by type of economic activity, and develops an author's approach to the classification of risks taking into account the specific conditions of agricultural enterprises. The conceptual apparatus of the terminology of the chosen topic is thoroughly analyzed. The factors that determine the risk in the economic activity of agricultural enterprises are analyzed and generalized. The authors identify the features of the risk management process in the context of enterprise management, its components. The original classification of risks faced by agricultural enterprises in the course of their economic activity is presented. It is concluded that the proposed classification may be of practical interest to economic entities and can be used as a model to create their own qualification table taking into account the sectorial characteristics of agricultural production and become one of the tools for management decisions to build an effective risk management system of enterprise.

Keywords: risks of agricultural enterprises, risk classification, management, agricultural production, risk management.

Постановка проблеми. На даному етапі розвитку економіки країни аграрний сектор має найбільш ризиковану сореру діяльності. Ризики аграрних підприємств являють собою предмет наукових досліджень, так як мають значний вплив не тільки на діяльність господарюючих суб'єктів, а й на продовольчу безпеку держави в цілому. Умови функціонування та розвитку підприємств аграрного сектору носять досить специфрічний характер, який не властивий іншим галузям, наприклад:

- залежність від природних умов;

- сезонність виробництва;

- складнощі, пов'язані з впровадженням інновацій;

- регіональні, галузеві, фрункціональні, технологічні та організаційні фрактори та особливостей діяльності з урахуванням участі живих організмів у виробничому процесі тощо [1].

Також слід зазначити, що у вітчизняній і зарубіжній економічній літературі представлені здебільшого загальні принципи управління підприємствами і виробництвом в умовах невизначеності та ризику. Однак концептуальні та методичні основи виявлення, аналізу та подолання ризиків у діяльності аграрних підприємств представлені лише фррагментарно. В економічній літературі недостатньо уваги приділено дослідженням методичних основ фрормування системи ризик менеджменту в аграрному секторі, а також моделюванню, прогнозуванню і управлінню ризиками, здебільшого наукові напрацювання в цьому напрямі стосуються фрінансових установ. У зв'язку з цим виникає гостра потреба визначення і розробки концепції управління ризиками, яка б враховувала вже існуючі нау- кові надбання 3 врахуванням особливостей фрункціонування аграрного сектору. При фрормуванні дієвого методичного підходу, також, не менш важливим $є$ удосконалення класифікації ризиків у сільському господарстві для їх кращого розуміння.

Аналіз останніх досліджень і публікацій. Проблемам визначення економічних ризиків і їх класифрікації присвячена достатня кількість наукових праць вітчизняних і зарубіжних вчених. Серед них можна виділити Дж. М. Кейнса, Г. Марковіца, А. Маршалла, Дж. Мілля, Ф. Найта [2], А. Сміта, Г. Великоіваненка [3], В. Вітлінського [3], В. Гранатурова [4], І. Литовченка [4], О. Дуброви [5], С. Клименка [5]. Дослідженням теоретичних і прикладних засад ризик менеджменту підприємств присвятили свої праці: В. Амбросов, Р. Біловол, М. Дем'яненко [6], В. Гросул [7], І. Єпісранова [8], І. Макаренко [9], О. Терещенко [10] та інші.

Виділення невирішених раніше частин загальної проблеми. Наразі, незважаючи на значну кількість, ґрунтовність і комплексність проведених досліджень, окремі питання які зорієнтовані на розробку ефективних інструментів і механізмів передбачення ризиків їх класифрікації у фрункціонуванні та розвитку сільськогосподарських підприємств в економічній літературі не отримали однозначних думок.

Формулювання цілей статті (постановка завдання). Саме це і обумовило вибір завдань та мету даного дослідження, що полягають в удосконалені класифрікації ризиків й поглиблені теоретичних і методичних засад визначення, аналізу і подолання їх на підприємствах аграрного сектору. 
Виклад основного матеріалу дослідження. Відсутність єдності у тлумаченні сутності поняття «ризику аграрних підприємств» спричиняє складність ідентифрікації кризового стану. На думку О. Андрушко, це пов'язано, головним чином, з тим, що кризовий стан становить сукупність багатьох кризових явищ [11]. К. Цапко акцентує увагу на тому, що «кризовий стан підприємства, це незапланований і небажаний, обмежений за часом процес, що спроможний істотно перешкодити або навіть унеможливити фоункціонування підприємства» [12].

Кризовий стан підприємства еволюціонує від проявів ризику до настання кризових явищ, що переходять у кризову ситуацію та стан ризику i, за відсутності квалісрікованого управлінського впливу, завершується критичною точкою - банкрутством. Проявами ризику є відхилення фрактичних показників діяльності від запланованих, які можуть спричинити істотні зміни у функціонуванні та стані підприємства. У свою чергу, під кризовим явищем розуміють погіршення певних показників фуункціонування підприємства, що справляють негативний вплив на процеси його життєдіяльності і стають моментом загострення протиріч, що виникають у процесі взаємодії окремих елементів підприємства, як усередині, так із зовнішнім середовищем [12]. Якщо дестабілізуючий вплив зовнішніх та внутрішніх чинників підприємницької діяльності активізується (збільшуються за кількістю, підвищується сила їх впливу, особливо для господарюючих суб'єктів аграрного сектору, які залежать також і від природно кліматичних й антропогенних фракторів), а система управління ризиками не встигає реалізувати необхідні ефрективні управлінські рішення, підприємство починає втрачати прибутки, а іноді і майно [13].

Головна задача класифрікації ризиків полягає в максимальній оптимізації представленої інфрормації про ризики в якості бази визначення використання тих чи інших методів і способів управління ними. На сьогодні не існує загальної думки й у виділені ознак та принципів класифрікації ризиків. В основному керуються при їх описі двома принципами: по конкретному змісту кожного типу і виду ризиків або за сфрерою господарської діяльності та поділом їх на групи 3 метою управління ними в залежності від джерела і етапу виникнення й можливості використання відповідного способу.

Ризики за ссрерою діяльності класифрікуються в залежності від характеру очікуваного результату також на дві основні групи: чисті та спекулятивні. У свою чергу, враховуючи взаємозв'язки ризиків, у кожній групі відбу- вається поділ на підгрупи, види та різновидності. Дана класифрікація необхідна на сам перед, на етапі ідентифрікації ризиків, оскільки являє собою їх широкий перелік і дає основу для характеристики можливих наслідків. Однак вона, не зважаючи на ступінь деталізації, не дає можливості виділити та охарактеризувати всі існуючі потенційні ризики через неминуче їх дублювання, що ускладнює вибір загального підходу і методу управління ними. А оскільки умови функціонування аграрних підприємств мають специфрічні особливості, які не притаманні іншим галузям (залежність від погодних (кліматичних) умов, сезонний характер, особливості використання технологій та специфічних засобів і фрорм виробництва), то вважаємо, що більш доцільно ризики аграрного сектору класифрікувати за принципом поділу їх на групи (рис. 1).

Результати запропонованого підходу класифрікації свідчать про можливість створення оригінального методу за допомогою якого підприємство може самостійно здійснювати групування власних ризиків, опираючись на відносно чіткі визначення за окремими групами ризиків, умовами і специсрікою своєї діяльності. Основною складовою даного методу являється практичний розподіл ризиків окремого підприємства за власною системою управління ними. Виходячи 3 цього підходу при розгляді ризиків аграрних підприємств можна виділити одинадцять загальних груп, які в свою чергу містять власні підгрупи та можуть бути об'єднати в окремі категорії (за напрямами діяльності підприємства). Так, група ризиків, що виділяються за термінами впливу, можуть поділятися на довготривалі, середньострокові та короткочасні (одиничні).

Класифрікаційний признак поділу за підприємницькою діяльністю передбачає підприємницькі та не підприємницькі ризики, що свідчить про відмінності між видами діяльності, яку можуть здійснювати господарюючі суб'єкти. Під підприємницьким ризиком розуміється, ризик, що виникає у наслідок фрінансово-господарської діяльності підприємства 3 метою отримання прибутку, та на практиці існують і не комерційні організації (благодійні фронди), що також можуть відчувати вплив ризику.

За ступенем сприйняття ризики діляться на мінімальні (рівень можливих збитків та негативних наслідків в межах до 20\%), припустимі (можливість втрат до 40\%), не припустимі (характеризуються рівнем можливих негативних наслідків до 65\%) та катастрофрічні (можливість втрат від 65-100\%). 


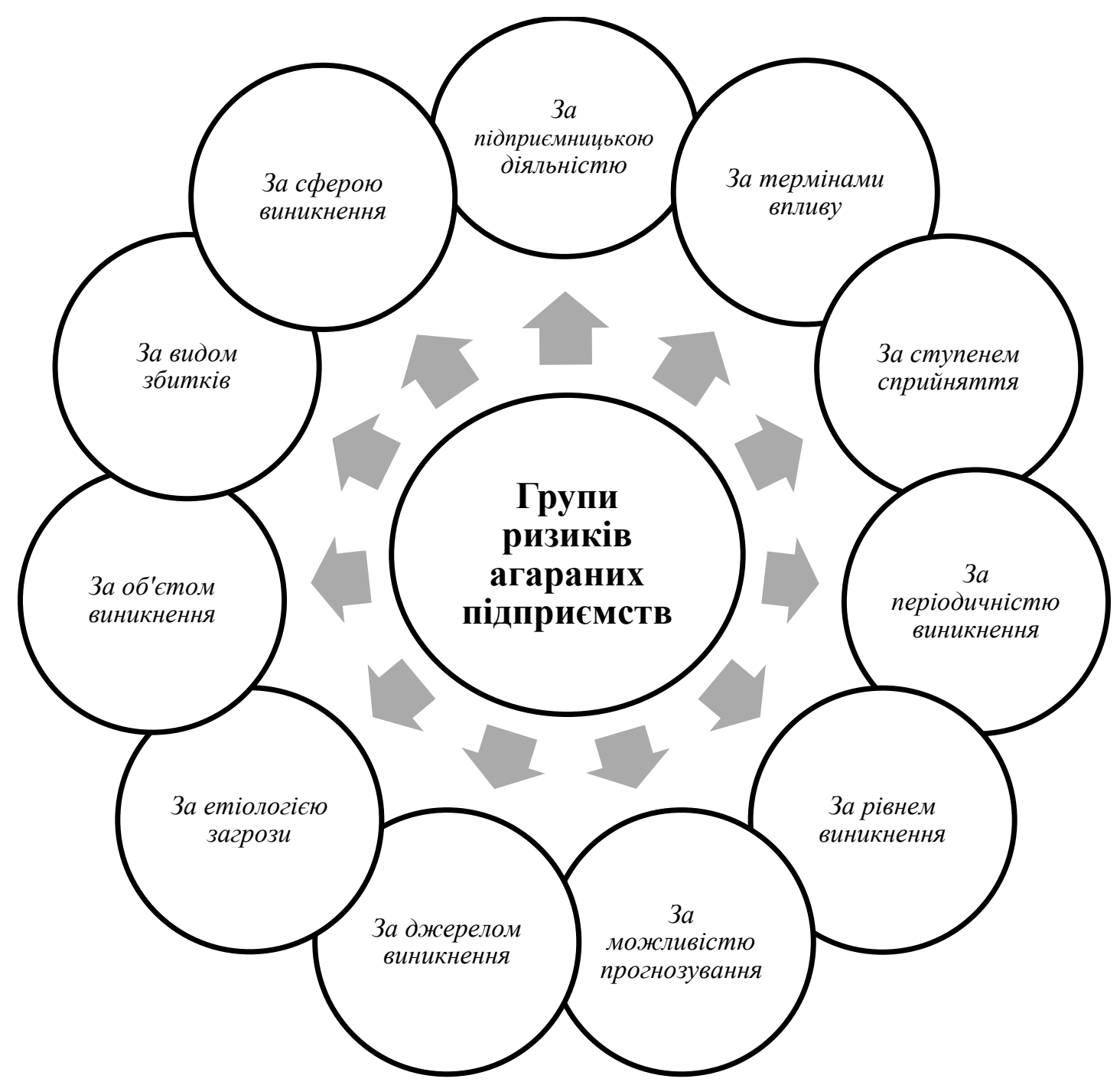

Рис. 1. Класифрікація ризиків аграрних підприємств за групами

Джерело: складено авторами

За періодичністю виникнення ризики бувають системними (як правило їх виникнення обумовлено самою системою і ступінь їх прояву знизити неможливо) та не системні (виникають не часто та їх можна нівелювати).

Рівень виникнення ризику також відіграє важливу роль при прийняті рішення, щодо вибору підходів і методів управління ними. За даною групою ризики діляться: на галузеві й міжгалузеві - залежать від ссрери діяльності, а в аграрному секторі можуть діляться на ризики галузей рослинництва чи тваринництва та операційні (виробничі) ризики (мікрорівень), регіональні (мезорівень), державні (макрорівень) та глобальні.

За можливістю прогнозування ризики можна поділити на прогнозовані (які можливо передбачити) і не прогнозовані (виникають спонтанно внаслідок фрорс-мажорних обставин).
За джерелом виникнення вони залежать від фракторів внутрішнього та зовнішнього середовища підприємства. В сільському господарстві також можна виділити ризики, які залежать від об'єкту виникнення: вирощуваних й перероблюємих підприємством сільськогосподарських культур, видів тварин, що утримуються та оснащення і устаткування агропідприємства. За етіологією ризики агросектору класифрікуються на антропогені (залежать від впливу людини) і природні (викликані природними силами).

За видом збитків виділяють наступні ризики:

1. Матеріальні ризики - витрати які з'являються за непередбачуваними обставинами реалізації проекту або планів виробництва, додаткових чи прямих витрат майна, устаткування, енергії і ресурсів.

2. Трудові ризики - пов'язані зазвичай з витратами робочого часу, трудових ресурсів тощо. 
3. Фінансові ризики - пов'язані з отриманням грошового збитку, який викликаний непередбачуваними платежами (виплатою штрасрів), або не поверненням боргів, чи неотриманням коштів за реалізовану продукцію тощо. Вони напряму пов'язані з фрінансовою діяльністю підприємства (фрінансування оборотного капіталу; залучення фрінансових ресурсів; фрінансування інвестицій; накопичення дебіторської заборгованості; бухгалтерський або податковий облік; обслуговування позик; розміщення вільних фрінансових ресурсів та розподілу прибутку). Для більш зручної класифрікації видів фрінансових ризиків, пропонуємо їх узагальнити і представити за групами: кредитні; ризики ліквідності; інвестиційні; податкові; ризики планування.

До найбільш широкої класифрікації ризиків слід віднести групування за сорерою виникнення.

Треба відмітити, що ризики аграрних підприємств дуже специсрічні і обумовлені умовами їх господарювання. Класифікація ризиків сільськогосподарських підприємств має галузеве забарвлення і при цьому суміщає загально прийняті види ризиків, які притаманні будь-якому господарюючому суб'єкту.

Висновки. Запропонована класифрікація може бути пристосована і перебудована для кожного окремого підприємства в залежності від випадку чи ситуації, в яких воно знаходиться. Для кожної задачі класифрікація ризику може мати самостійне рішення, так як природа ризику, супроводжується по-перше видом діяльності та має свою визначену специфріку, яка задає доцільність наявності в системі класифрікації тих чи інших ознак. Виходячи з вищезазначеного, можна зробити висновок, що запропонована класиорікація може представляти практичний інтерес для господарюючих суб'єктів і використовуватися в якості моделі для створення власної кваліфрікаційної таблиці з урахуванням галузевих особливостей агровиробництва та стати одним з інструментів при прийнятті управлінських рішень, щодо побудови ефективної системи ризик менеджменту на підприємстві.

\section{СПИСОК ВИКОРИСТАНИХ ДЖЕРЕЛ:}

1. Танклевська Н. С., Кириченко Н. В. Активізація та ефективність впровадження інновацій аграрними підприємствами : монографрія. Херсон : Грінь Д.С., 2015. 216 с.

2. Найт Ф. Риск, неопределенность и прибыль / Пер. с англ. Москва : Дело, 2003. 360 с.

3. Вітлінський В. В., Веливоіваненко Г. І. Ризикологія в економіці та підприємництві : монографрія. Київ : KHEУ, 2004. 480 C.

4. Гранатуров В. М., Литовченко И. В. Управление предпринимательскими рисками: вопросы теории и практики. Одесса : МУП Эвен, 2005. 204 с.

5. Клименко С. М., Дуброва О. С. Обгрунтування господарських рішень та оцінка ризиків : навч. посіб. Київ : КНЕУ, 2005. 252 c.

6. Дем'яненко М. Я. Фінансова криза в аграрному секторі АПК. Економічні науки. Серія : Облік і фрінанси. 2010. № 7(1). С. 408-414.

7. Гросул В. А. Механізм управління антикризовою стійкістю підприємства на основі методології когнітивного моделювання. Economic efficiency of business in the conditions of unstable economy : Collective monograph. Aspekt Publishing, Taunton, MA, United States of America, 2015. P. 37-45.

8. Єпіфанова І. Ю. Сутність антикризового управління підприємства. Економіка та суспільство. 2016. № 2. C. 265-269.

9. Макаренко І. О. Алгоритм антикризового управління підприємством. Актуальні проблеми економіки. 2005. № 3. C. 104-109.

10. Терещенко О. О. Інститут фрінансового контролінгу - інноваційна платфрорма для корпоративних фрінансів і контролінгу. Бухгалтерський облік і аудит. 2014. № 5. С. 52-53.

11. Андрушко О. Б. Аналіз моделей діагностики кризового стану та загрози банкрутства підприємства. Вісник Національного університету «Львівська політехніка» : Збірник наук. праць Менеджмент та підприємництво в Україні: етапи становлення і проблеми розвитку. 2005. № 547. С. 9-21.

12. Цапко К. О. Дослідження наукових підходів до визначення та оцінки кризового стану підприємства. Управління розвитком. 2012. № 2. С. 173-176.

13. Бабіна Н. О. Антикризовий фрінансовий контролінг як фрактор забезпечення економічної безпеки підприємства. Ефективна економіка : електронне наукове фрахове видання. № 5. 2014. URL: www.economy.nayka.com.ua 


\section{REFERENCES:}

1. Tanklevska N.S. and Kyrychenko N.V. (2015) Aktyvizatsiia ta efektyvnist vprovadzhennia innovatsij ahrarnymy pidpryiemstvamy [Activation and efficiency of introduction of innovations by agrarian enterprises: monograph]. Kherson: Hrin D.S.

2. Najt F. (2003) Risk, neopredelennost i pribyl [Risk, uncertainty and reward]. Moscow: Delo.

3. Vitlinskyj V.V. and Velyvoivanenko H.I. (2004) Ryzykolohiia v ekonomitsi ta pidpryiemnytstvi [Riscology in economics and business]. Kyiv: KNEU.

4. Granaturov V.M. and Litovchenko I.V. (2005) Upravlenie predprinimatelskimi riskami: voprosy teorii i praktiki [Business risk management: theory and practice]. Odessa: MUP Jeven.

5. Klymenko S.M. and Dubrova O.S. (2005) Obhruntuvannia hospodarskykh rishen ta otsinka ryzykiv: navch. posib. [Establishment of state solutions and assessment of risiks]. Kyiv: KNEU.

6. Demianenko M.Ya. (2010) "Financial crisis in the agrarian sector of the agro-industrial complex". Ekonomichni nauky. Ceriia: Oblik i finansy, vol. 7(1), pp. 408-414.

7. Hrosul V.A. (2015) Mekhanizm upravlinnia antykryzovoiu stijkistiu pidpryiemstva na osnovi metodolohii kohnityvnoho modeliuvannia [Economic efficiency of business in the conditions of unstable economy: Collective monograph]. Aspekt Publishing, Taunton, MA, United States of America.

8. Yepifanova I. Yu. (2016) "The essence of the anti-crisis management of the enterprise". Ekonomika ta suspilstvo, vol. 2, pp. 265-269.

9. Makarenko I.O. (2005) "Algorithm for anti-crisis management of an enterprise". Aktualni problemy ekonomiky, vol. 3, pp. 104-109.

10. Tereschenko O.O. (2014), "Institute of Financial Control - an innovative platform for corporate finance and control". Bukhhalterskyj oblik i audyt, vol. 5, pp. 52-53.

11. Andrushko O.B. (2005) "Analysis of models for diagnostics of a crisis stagnation and contamination of bankruptcy of an enterprise". Visnyk Natsionalnoho universytetu «Lvivska politekhnika»: Zbirnyk nauk. prats Menedzhment ta pidpryiemnytstvo v Ukraini: etapy stanovlennia i problemy rozvytku, vol. 547. pp. 9-21.

12. Tsapko K.O. (2012) "Research of scientific approaches to the definition and assessment of the crisis of the enterprise". Upravlinnia rozvytkom, vol. 2, pp. 173-176.

13. Babina N.O. (2014) "Anti-crisis financial controlling as a factor in ensuring the economic security of the enterprise". Efektyvna ekonomika: elektronne naukove fakhove vydannia, vol. 5. URL: www.economy.nayka.com.ua 